https://doi.org/10.17048/AM.2020.199

\title{
Pacsuta István
}

EKE-GTK-TTI Szociálpedagógia Tanszék

pacsuta.istvan@uni-eszterhazy.hu

\section{Hallgatók infokommunikációs szokásai értékválasztásuk mentén}

\begin{abstract}
Absztrakt
Alapvető célunk, hogy számos korábbi vizsgálat adatbázisát felhasználva megalkossunk egy kategóriarendszert, amelynek felhasználásával megismerhető a fiatalok - szúkebben véve a felsőoktatásban részt vevő hallgatók - értékválasztása, annak motivációi. Ehhez elengedhetetlen, hogy a korábbi elemzéseink során kialakított értékrendszerek érvényességét ellenőrizzük. Tervezett előadásunkban arra keressük a választ, hogy a „kapcsolatorientált” hallgatók valóban aktívabbak a közösségi média által kínált lehetőségek kihasználásában, infokommunikációs szokásaik összhangban vannak-e értékválasztásukkal?
\end{abstract}

A kérdőívvel történt adatfelvételek során használt értéksor a World Value Survey (WVS) által használt értékeken, értéksoron alapszik (Inglehart, 2000 és Inglehart - Baker, 2000). A Regionális Egyetem Kutatócsoport 2005-ös és 2010-es kérdőives lekérdezésen alapuló adatbázisát felhasználva korábban meghatároztuk a hallgatói „értékcsoportokat”, feltártuk a hallgatók értékstruktúráját. A 2016-os Magyar Ifjúságkutatás adataira támaszkodva (A Kutatópont Kft. engedélyével) lehetőségünk nyílik arra, hogy az eddigi eredményeinket, kategóriáinkat összevessük egy jóval nagyobb minta, azaz a Kárpát-medence fiataljainak értékstruktúrájával, az általunk felállított kategóriák érvényességét ellenőrizzük.

Az eredményekből kiderül, hogy az értékválasztás során felmért attitűd jellegű választások, vagyis az értékek rangsora milyen mértékben jár együtt az infokommunikációs eszközök használatából következtethető közösségiorientált viselkedéssel. Másként fogalmazva a „kapcsolatorientált” hallgatók mennyivel aktívabbak „,anyagias” társaiknál?

Nagyobb ívű elméleti vonatkozású vállalásunk, hogy megalkossunk egy, az ifjúságra alkalmazható értékrendszer-kategóriát, amely az ifjúság megváltozott társadalmi körülményei között is alkalmazható. Gyakorlati szempontból az értékrendszerek megfelelő alátámasztottság mellett egyéb társadalmi cselekvések esetén is prediktív funkcióval bírhatnak, vagyis az értékválasztás alapján regisztrálható 
különbségek a társadalmi élet különböző színterein (oktatás, munka világa, közösségi kapcsolatok) eltérő viselkedéseket vetítenek előre.

Kulcsszavak: ifjúság, érték, közösség

\section{Students' info communication habits along their value choice}

Our basic aim is to establish a category system using the database of many previous research, and by using this category system to learn about the value choice, and the motivation behind that value choice of the youth - more narrowly the value choice of students in higher education. To do so, it is essential to check the validity of the value systems established during our previous analysis. In our planned presentation we are looking for the answer whether "relationship-oriented" students are really more active in taking the advantages of the opportunities offered by social media, and whether their infocommunication habits are in line with their value choices.

The values used in the survey are based on the values, value- lines applied by the World Value Survey (WVS) (Inglehart 2000 and Inglehart -Baker, 2000). Using the database of the 2005 and 2010 survey of the Regional University's research team, we determined the "value groups", and we explored the value structure of the students.

Relying on the data from 2016 Hungarian Youth Research (with the permission of Kutatópont Kft.) we have the opportunity to compare our current results and categories against a considerably greater sample, namely against the value structure of the youth of the Carpathian Basin, therefore we can check the validity of the categories we established.

The results show the extent to which the attitude-type choices assessed during value-selection, namely the ranking of values, are associated with community-oriented behaviour, that can be concluded from the use of infocommunication tools. In other words, how much more active "relationship-oriented" students are than their "material-oriented" peers.

Our broader theoretical commitment is to create one value system category valid for the young which can also be applied in the changed social circumstances of the youth. From a practical point of view, value systems, with adequate support, can have a predictive function in case of other social actions, namely the differences registered in value choice project different behaviours in other spheres of social life (education, world of work, community relations).

Keywords: youth, value, community 


\section{Bevezetés}

A 60-as, 70-es évektől kezdődően egyre több kutatás és elmélet fókuszál a fiatalok társadalmi helyzetére, társadalmi szerepére. Ettől az időszaktól datálható az a folyamat, amelynek során az ifjúság „láthatóvá" válik a társadalmi struktúrában, a korábbitól eltérő kulturális csoportosulásként jelennek meg a társadalmakban. Ez eleinte főként a nyugat-európai térségre jellemző, de hamarosan éreztette hatását a „keleti blokkban” is. Manapság már nem kérdőjelezhető meg a korábban lezajlott folyamatok eredményeként kialakult ifjúsági szubkultúra, az a jelenség, hogy életmódjukkal, életvitelükkel eltérnek bármelyik más korosztály szokásaitól, lezajlott az „ifjúsági korszakváltás” A szocializáció folyamatát tekintve mintakövetőkből részben mintaadókká válnak. (Mead, 2006)

Ez a korosztály - bár nehezen köthető életkorhoz - önálló csoportot alkot a társadalmi struktúrában, ennek alapja a kulturális különállás. (Zinnecker, 2006) Ennek a sajátságos kultúrának egyik fontos eleme, az elkülönülés alapja, hogy értékválasztás mentén is eltérnek a társadalom más csoportjaitól, azaz más értékrendszer mentén szervezik életüket. Az ifjúsági korszakváltásnak egyik fő színtere a felsőoktatás, a felsőoktatásban eltöltött időszak, amely a fiatalok egyre nagyobb hányadát érinti. (Gábor 2006). Ráadásul ez az időszak az, amelyben a fiatalok lassan belépnek a felnőttek világába, így identitásukkal kapcsolatos feladataik, útkereséseik időszaka is.

$A z$, hogy eltérő értékstruktúrával rendelkeznek, a hétköznapi életük során is megmutatkozik, más időbeosztással, más tevékenységekkel töltik szabad idejüket, azaz életmódjuk is eltérő. Ebben az eltérésben kitapintható az IKT eszközökhöz való eltérő viszonyulás, vagyis az eltérő eszközhasználat (Twenge, 2018), amely kijelentés ma már közhelyszerűen hat. Jelen írásunk központi kérdése, hogy az értékválasztás során felmért attitűd jellegű választások, tehát az értékek rangsora milyen mértékben jár együtt az infokommunikációs eszközök használatából következtethető közösségiorientált viselkedéssel. Másként fogalmazva: a „kapcsolatorientált" hallgatók mennyivel aktívabbak „anyagias” társaiknál?

A vizsgálathoz a korábbi években megalkotott kategóriákat, a hallgatók értékválasztás alapján meghatározott „értékcsoportjait” használjuk fel. Kiindulópontunk a harmadfokú képzés hatása a regionális átalakulásra" címú OTKA kutatás (2010) adatbázisa volt, amelynek segítségével csoportosítottuk a felsőoktatásban részt vevő hallgatókat, majd ezeket a kategóriákat alkalmaztuk a Magyar Ifjúság 2016-os kutatás adatainak elemzésekor. Jelen tanulmányban az észak-alföldi minta eredményeit mutatjuk be, életkor tekintetében az 1987 és 2001 között született fiatalokról lesz szó, azaz 1529 évesek, összesen 1360 fő. 


\section{Az érték-csoportok}

\section{1. ábra A fiatalok értékválasztása 2016-ban}

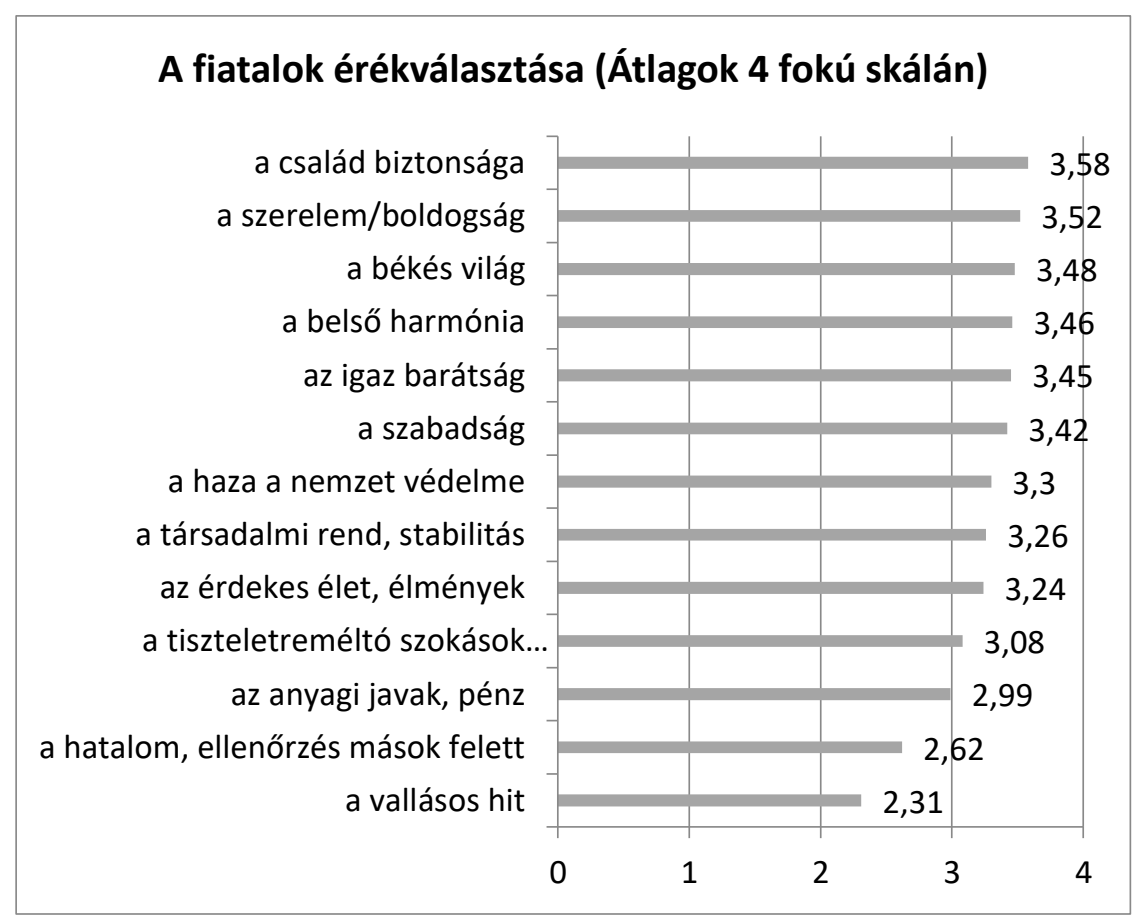

A magyarországi értékvizsgálatok során már megszokhattuk, hogy a család, a családdal kapcsolatos értékek első helyen szerepelnek. Az igazán érdekes eredmények ezután következnek. Igaz barátság, Szabadság, Szerelem/boldogság az első „blokk” értékei, mind 3,5 közeli átlagokat értek el egy négyfokozatú skálán. Kiolvasható a kortárs kapcsolatok fontossága, és az élménykeresés. A békés világ szintén az élmezőnybe került, viszont a közelmúlt eseményei/hírei mindig jelentős hatással vannak erre az itemre. A média által támogatott érzékenység, fokozott figyelem a bevándorlással, terrorizmussal kapcsolatban emeli ennek az itemnek az értékét. A középmezőny leginkább az önmegvalósításra, biztonságra vonatkozó értékeket tartalmazza. Belső harmónia, Érdekes élet, élmények - mind az egyén belső életére vonatkoztatható, a fiatalok individualizálódására enged következtetni (bővebben: (Pacsuta, 2014). Ezek mellé a Társadalmi rend, Anyagi javak, a Haza, Nemzet védelme, Tiszteletre méltó szokások megőrzése - amelyek a stabilitást, és az önmegvalósítás feltételeit jelentik. A politikától való elfordulás és a szekularizáció jelensége szinte már társadalmi közhely. A fiatalok a hatalom mellett ezeket az értékeket sem tekintik fontosnak. Összességében a fiatalok értékválasztása hűen tükrözi életkori sajátosságaikat. A vallásos hit, mint érték megosztja a fiatalokat, ez az item produkálja a legnagyobb szórást, azaz a legnagyobb eltérések ebben az esetben regisztrálhatók. A tradíció, vallás és hatalom dimenziói háttérbe szorulnak. 
Eredményeink alátámasztják a számos, más kutatás elméleti alapjául szolgáló Inglehart kijelentéseit. A fiatalok számára egyre kevésbé fontosak az anyagi javak (hiszen azok elérhetők), a tartalmas emberi kapcsolatok, a kultúra, a szabadság, függetlenség válnak fontossá. (Inglehart, 2000 és Inglehart - Baker, 2010)

Feltáró jellegű faktorelemzést alkalmaztunk, hogy megállapíthassuk az egyes, esetleges értékcsoportokat. A korrelációs mátrix alapján úgy döntöttünk, hogy elegendő együttjárásunk van a vizsgálat lefolytatásához. Az előzetesen lefuttatott „feltáró” Kaiser-kritérium 4 faktort határozott meg. Az eljárás során szükségünk volt „rotálásra”, ezért a varimatrix módszerrel kaptuk meg a véglegesnek tekintett eredményeket. A 2010-ben történt lekérdezés adatain, a kapott faktorok a teljes szórás 52\%-át magyarázzák. Az egyes faktorok végleges elnevezése részben más kutatás kategóriáira támaszkodik, néhol saját fogalomhasználattal éltünk.

Az első faktorba a Változatos élet, Érdekes élet, élmények, Eredetiség, fantázia, Szabadság, Műveltség, Belső harmónia értékek kerültek „Individualista” elnevezéssel.

Az értékek második csoportjába A család biztonsága, Szerelem/boldogság, Igaz barátság értékek szerepelnek „Emberi kapcsolatok” néven.

A harmadik csoportba a Tiszteletreméltó szokások megőrzése, A haza, a nemzet védelme, megtartása, Vallásos hit, Békés világ, Társadalmi rend, stabilitás került besorolásra, ezek alapján „Tradíció” néven.

Végül, a negyedik csoportba a Hatalom, ellenőrzés mások felett, Anyagi javak, pénz, Politika, közélet szerepelnek, „Anyagi-hatalmi” faktor néven.

A faktorok alapján megalkotott klasztereket és azok elnevezéseit a 2. számú ábra mutatja be.

2 ábra A hallgatói klaszterek

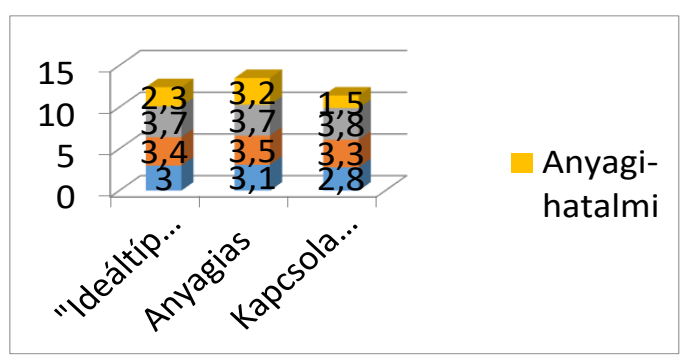




\section{A felhasználói szokások}

A fiatalok közösségi oldalakra vonatkozó felhasználói szokásai meglehetősen homogén képet mutatnak. „A magyarországi 15-29 évesek több mint háromnegyede (79\%) tagja valamilyen internetes közösségi oldalnak, amely 2016-ban is leginkább a Facebook-ot jelenti." (Székely, 2016:63) Több, mint háromnegyedük (80\%) naponta ellátogat a legelterjedtebb közösségi oldalra (Facebook). A motiváció szempontjából leginkább szórakozásra és információszerzésre használják, bár a két tényező szétválasztása meglehetősen nehézkes, hiszen az "érdekességek” olvasgatása mindkét kategóriát lefedheti. Az sem meglepő, hogy a vizsgált korosztály esetén is megfigyelhető, hogy az életkor növekedésével csökken a regisztráltak aránya, a fiatalabbak, már „belenőnek” az informatikai eszközök használatába. (Id.: Twenge, 2018)

Ezek ismeretében nem meglepő, hogy minden második 15-29 éves úgy érzi, hogy egy napnál tovább nem tudná nélkülözni az okostelefonját (54 \%), internetet (51 \%), és az általa használt közösségi oldalt (44\%). Ezek fényében vizsgáljuk meg, hogy a felsőoktatásban tanuló társaik milyen felhasználói szokásokkal rendelkeznek, azaz milyen sajátosságokat mutatnak. Kiemelt figyelmet fordítva arra, hogy az értékválasztás alapján közösségorientáltabbnak tekinthető hallgatók hogyan használják a közösségi oldalakat más társaikhoz képest.

A közösségi oldalak látogatásának gyakoriságát egy ötfokú skálán méri a 2016-os ifjúságkutatás, ahol az 1-es a „naponta többször”, míg az 5-ös a „soha” kategóriát jelöli. A hallgatók esetén is a Facebook jelenti a közösségi oldalak legnépszerúbb formáját, 1,71-es átlaggal, 1 alatti szórással, míg a sorban az Instagram követi, jóval lemaradva 4,1-es átlaggal és majd 1,5-es szórással. Talán nem tévedünk nagyot, ha a legnépszerübb oldal, a Facebook felhasználói mintázatai alapján vonjuk le következtetéseinket, hiszen a legdominánsabb közösségi oldalról beszélünk.

\section{3. ábra A Facebook használatának gyakorisága a hallgatói csoportokban}

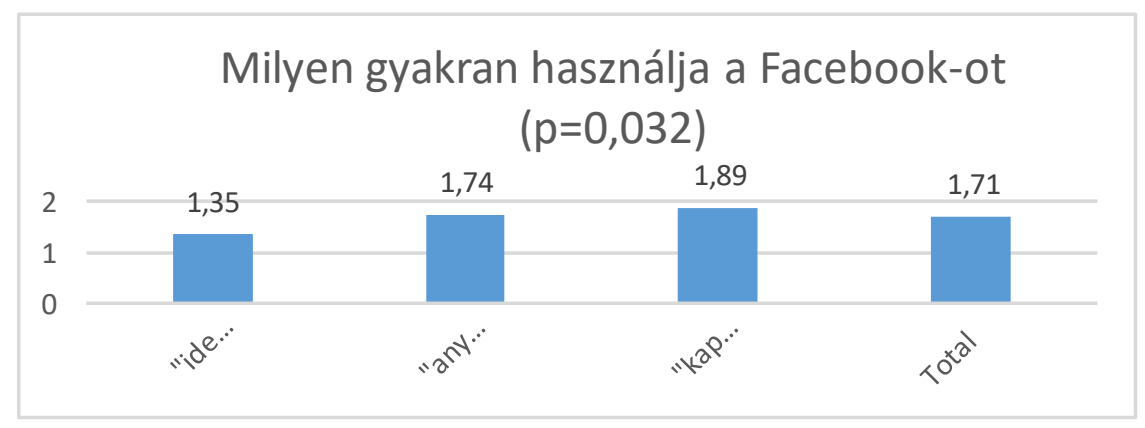

A különböző hallgatói típusok felhasználói szokásait ábrázolja a fentebbi ábra, tehát az általánosnak tekinthető „ideáltipikus” hallgató a legaktívabb, míg a „kapcsolatorientált” társaik a legkevésbé aktívak ezen az oldalon, bár a megfigyelt szórás is az ő esetükben a legmagasabb. 
Az eltérés szignifikánsnak tekinthető. Az Instagram esetén az „anyagiasak” mutatkoznak aktívabbnak, igaz az eltérés mindössze 1 tized, és ennek az oldalnak az esetén is a „kapcsolatorientáltak" a legkevésbé érdekeltek. Minden egyes közösségi oldal esetén ez a tendencia bontakozik ki, azaz a kapcsolatorientált hallgatók a legkevésbé aktívak a közösségi oldalakon, igaz a Facebooktól eltérően kisebbek a különbségek.

\section{4. ábra A kapcsolatok átlagos száma a hallgatói csoportokban}

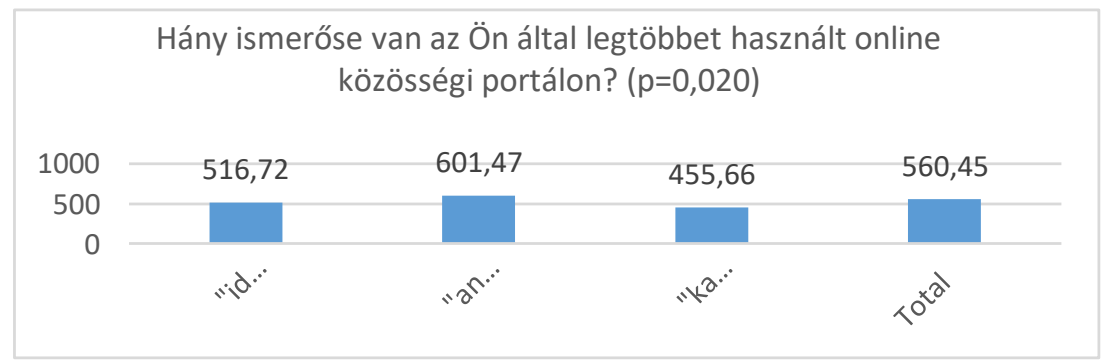

Ha a kapcsolatok számosságát vizsgáljuk az „anyagias” hallgatók rendelkeznek a legtöbb kapcsolattal (601-átlagosan), míg a „kapcsolatorientált” társaik ennek háromnegyedét produkálják, azaz átlagosan 455 kapcsolatot tartanak számon. Szakirodalmi tény, miszerint valóban új közösségek jelentek meg a technikai fejlődésnek és a globális társadalmi változásoknak köszönhetően. A virtuális közösségek, az IKT eszközökön keresztül létrejövő közösségek kiterjedése sokkal nagyobb, vagyis az egyén egy sokkal nagyobb közösségnek válik a tagjává az online térben, mint az offline térben.

Korábbi kutatásunk során megállapítottuk, hogy a közvetlen, személyesen múködtetett kapcsolati háló kiterjedésére a leginkább jellemző kapcsolati szám 10-100 közötti volt, azonban az online térben létrejövő közösségek esetében ez a szám jellemzően 200-400 közötti. Az adatok elemzése során az is kiderült, hogy azok a válaszadók, akik az offline térben nagyobb közösséghez tartoznak, azaz kapcsolati számuk magasabb, azok az online térben is törekednek arra, hogy kiterjedtebb kapcsolati hálóval rendelkezzenek, azaz nagyobb közösség tagjai legyenek. (Pacsuta - Hadnagy, 2018)

A 2016-os lekérdezés kitért arra is, hogy a különböző hozzáférések (okostelefon, internet, wifi, és a leggyakrabban használt közösségi oldal) milyen mértékben „kötik” a felhasználót, azaz mennyi időt bírna ki nélküle a válaszadó. Az 1-es kategória a „semennyit”, míg a 8-as érték a „bármennyit” fedte. Az alacsonyabb értékek a nagyobb mértékű „függést” jelölik. 


\section{5. ábra Az egyes hallgatói csoportok és a hozzáférés nélkülözésének toleranciája}

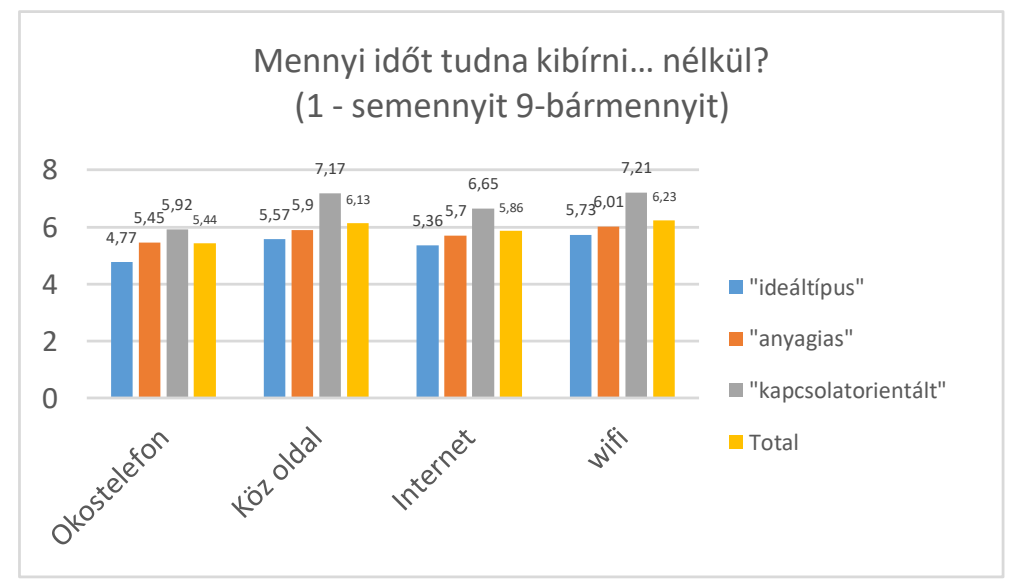

A fenti ábrán látható eltérések mind azonos mintázatot követnek. Ennek értelmében a legkevesebb időt a különböző hozzáférést biztosító eszközök nélkül az „ideáltipikus” hallgatók bírnának ki (vagyis így nyilatkoztak), míg a legtöbbet a „kapcsolatorientált” társaik. A legnagyobb frusztrációt a wifi hozzáférés és a közösségi oldalak látogatásának hiánya jelenti. (A közösségi oldalak esetén az eltérés szignifikáns $(p=0,049)$

Ezek ismeretében látható, hogy az értékválasztás alapján „közösségorientáltabbnak” vélt hallgatók közösségi oldalakra vonatkozó felhasználási szokásai eltérők a más értékrendszerbe sorolt társaiktól, a várt tendenciától eltérően épp, hogy kevésbé vannak jelen, kevésbé fontos számukra a közösségi oldalak által nyújtott szolgáltatás.

\section{Egy lehetséges magyarázat}

Joggal vetődik fel a kérdés, hogy mi okozhatja, azt a jelenséget, hogy az értékstruktúrában megjelenő közösségi irányultság nem kapcsolódik össze, sőt - távolítja a közösségi oldalak felhasználói aktivitását. Korábbi, kvalitatív kutatásunk eredményei ismeretében felvetődik, hogy a válasz a definíciókban keresendő. A hallgatókkal készített fókuszcsoportos interjúk során kiderült, hogy az értékek definiálása és az értékek hierarchiájának magyarázata felfedi azt a jelenséget, hogy jó néhány érték „eszköz" jelleggel szerepel, azaz valamely más érték érdekében tölt be kiemelkedő szerepet. (Pacsuta, 2018) Példaként megemlíthetjük, hogy a család, mint érték saját erőforrásként jelenik meg, nem a család intézményének fontossága olvasható ki a magyarázatokból. Azaz a „család, mint érték” mögött rejlő definíció eltér a szakirodalmi meghatározástól, eltolódik az „önös” irányultság felé, erőforrásként funkcionál az egyén számára - akár individualista színezettel is. Ennek ismeretében, kissé megfordítva a jelenséget, elképzelhető, hogy a közösségi oldalak „közösségi” jelzője szorul átgondolásra. A közösség fogalmából kiindulva. Segítségünkre lehet, ha az időfelhasználást tekintve megnézzük az 
online és offline kapcsolatok egymáshoz való viszonyát az ifjúság körében. Az alábbi ábra jól szemlélteti, hogy az interneten töltött idő a társaságban töltött idő rovására gyarapszik.

\section{6. ábra Azon 12. osztályosok aránya, akik heti 10 vagy annál több órát töltenek az interneten, és a személyes} társasági tevékenységek átlagos százaléka

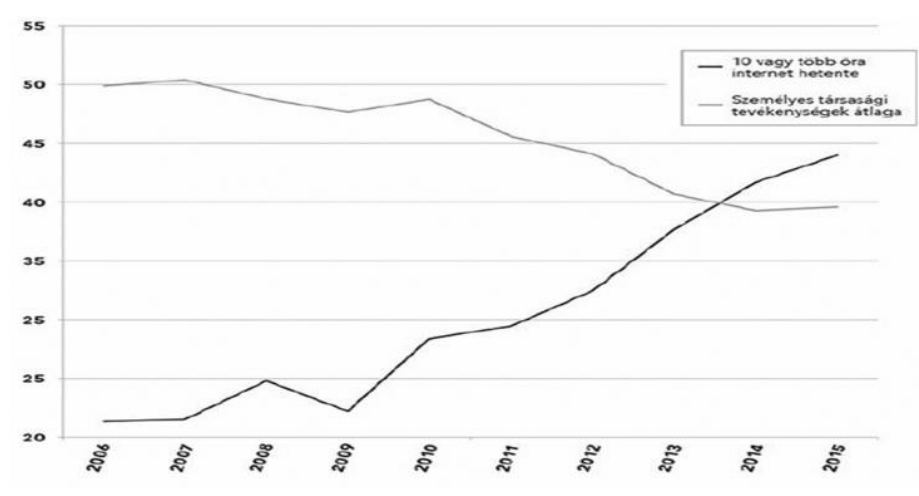

(Forrás: Twenge, 2018:95)

A polgári társadalmak kialakulásával, az egyén közösségek alóli felszabadulásával, az individualizációval, olyan folyamat vette kezdetét, amely során az egyéni szabadságok növekedésével a közösség egyénre gyakorolt hatása csökkent. Számos elmélet, elképzelés született azzal kapcsolatban, hogy ez hogyan alakítja át a társadalmakat. Max Weber az urbanizációval kapcsolatban a hagyományos közösségi alapoktól való felszabadulás lehetőségét, és a közösségi kötelékek gyengülését emelte ki. (Weber, 1967) Émile Durkheim a városi munkamegosztásból fakadó egymásrautaltság kapcsolatteremtő erejét, az organikus szolidaritást hangsúlyozta. (Durkheim, 2001) Ferdinand Tönnies az „újfajta szerveződés" jellemzői a közösség és társadalom fogalmak szembeállításával kívánta leírni, szintén kiemelve a fellazuló emberi kapcsolatok jelenségét. (Tönnies, 2004) Mindannyian a modernizáció társadalomra gyakorolt hatásaként írták le a közösségek egyénekre gyakorolt hatásának megváltozását. Az azonban a fogalom jellemzője, hogy a társadalmi integráció fontos szereplője, és lokális vonatkozással bír. Jó fél évszáddal később is ez a mérvadó jellemző, Talcott Parsons közösség definíciója: „a társadalmi rendszer szerkezetének egyfajta megjelenése, amelyik vonatkozhat személyek területi elhelyezkedésére és cselekvéseikre is" (idézi Szelényi, 1973: 15). Manapság azonban eltűnik a lokalitás fogalmának fontossága, mint a közösségek létrejöttének egyik tényezője (Henderson Thomas, 2002), majd a hálózatelemzés felszabadította a közösségkérdést a hagyományos értelemben vett közösség és szomszédság megközelítésétől, és újfajta dimenzióját nyitotta meg az emberi kapcsolatok elemzésének. (Wellman, 1988 idézi Hadnagy, 2016) Ezek értelmében a közösség fogalma olyan változásokon ment keresztül, amely tovább lazította azt, megfosztva a lokális kötöttségtől. Vitányi Iván ezt az első, másod és harmadfokú közösségek fogalmakkal írja le, számunkra a harmadfokú közössékel lesznek a fontosak, amelyekhez szabad választás alapján, az egyéni értékválasztá- 
sunk, érdeklődésünk alapján csatlakozunk. (Vitányi, 2006) Ennek a lehetőségét nyitotta ki az IKT eszközök használata, amelyek egymástól bármilyen távol levő emberek hálózatát képesek megteremteni. A kérdés az, hogy a közösségi oldalak által létrejött „közösségek” mennyiben töltik be a korábbi közösségek integráló funkcióját, mennyire tudják a manapság már jelentősen fragmentálódott társadalmak szövetét újra fonni. A válasz annak tükrében elgondolkodtató, hogy korábban láthattuk a közösségi oldalak felhasználói motívuma a szórakozás és információszerzés. A lehetséges magyarázat pedig az lenne, hogy a közösségorientált hallgatók alacsonyabb aktivitása az online térben arra vezethető vissza, hogy számukra az offline közösségek azok, amelyek betöltik a valós közösségek szerepét.

\section{5. Összegzés}

Az „előzménykutatásnak” tekinthető Eger Ifjúság 2016 elemzése során az értékválasztással nem találtunk szorosabb összefüggést, azaz a különböző értékcsoportokat preferáló fiatalok nem mutatnak lényeges eltérést a közösségi oldalak felhasználását illetően. (Pacsuta - Hadnagy, 2018) Néhány esetben tendenciákat sikerült megfogalmazni. Akkor a minta homogenitásával magyaráztuk ezt, hiszen életkorban, lakóhelyben meglehetősen homogén mintával dolgoztunk. A tágabb földrajzi keretek között, kifejezetten a felsőoktatásban részt vevő populáción viszont markáns különbségeket regisztrálhatunk. Eredeti elképzelésünk, hogy az értékválasztás alapján „kapcsolatorientált” hallgatók, azok, akiknek fontosabbnak bizonyulnak az emberi kapcsolatok ezeket a kapcsolataikat az online térben is ápolják. Több és intenzívebb kapcsolatot ápolnak az internet és a közösségi oldalak által nyújtott felületeken is. Az adatok ennek ellenkezőjére világítottak rá, az értékek mentén más választással bíró társaikkal ellentétben ők kevésbé használják a közösségi oldalak által nyújtott lehetőségeket, kevesebb kapcsolatot ápolnak ezeken a felületeken, jobban tolerálják a különböző IKT eszközök és szolgáltatások szüneteltetését. Az egyik lehetséges magyarázat, hogy a közösségi élményt nem az online térben keresik, hanem az offline kapcsolatokra koncentrálnak, ezzel megkérdőjelezve a közösségi oldalak „,közösségiségét”, közösségteremtő, integráló funkcióját. 


\section{Irodalomjegyzék}

Durkheim, Émile (2001): A társadalmi munkamegosztásról. Osiris, Bp.

Hadnagy József (2016): Közösségi kapcsolatok szerveződési sajátosságai a digitális térben, és ami mögötte van. In: Pacsuta István (Szerk.). Az IKT eszközök szociálpedagógiai vonatkozásai. Líceum Kiadó, Eger.

Henderson, Paul - Thomas N. David (1987. Skills in Neighbourhood Work National Institute Social Services Library No. 39. London, Allen and Unwin, Boston and Sidney

Inglehart, Ronald - Baker, Wayne E. 2000. Modernization, Cultural change and the persistence of traditional values. In: American Sociological Review, 2000/65. pp. 19-51.

https://doi.org/10.2307/2657288

Inglehart, Ronald 2000. Globalization and Postmodern Values. In: The Washington Quarterly 23/1. pp. $215-228$

\section{https://doi.org/10.1162/016366000560665}

Mead, Margaret (2006): Kultúra és elkötelezettség. A generációk közti új viszonyok a hetvenes években. In: Gábor Kálmán - Jancsák Csaba (szerk.): Ifjúságszociológia. Belvedere, Szeged.

Pacsuta István - Hadnagy József (2018): Az értékválasztás és a közösségi oldalak felhasználásának kapcsolata In: Agria Média 2017. Eger, Líceum Kiadó. pp. 166-174.

https://doi.org/10.17048/AM.2018.166

Pacsuta István (2014): Felsőoktatásban részt vevő hallgatók individualizálódása. In: Torgyik Judit (Szerk.). Sokszínű pedagógiai kultúra. pp. 100-106.

Pacsuta István (2017): A felsőoktatásban részt vevő hallgatók összehasonlító kvalitatív értékvizsgálata. In: Erdélyi Társadalom 2017; 15: 27-39.

Tönnies, Ferdinand (2004): Közösség és társadalom. FOK-TA Bt.

Twenge, Jean M. (2018): iGeneráció - Akik közösségi médián és okostelefonon nevelkedtek. Édesvíz Kiadó, Bp.

Vitányi Iván (2006): A magyar kultúra esélyei. MTA Társadalomkutató Központ, Bp.

Weber, Max (1967): Gazdaság és társadalom. KJK. Bp.

Wellman, Barry (1988): The Community Question Re-evaluated. In M. P. Smith (ed.): Power, Community and the city. Comparative Urban Research Vol.1. New Brunswick, Transaction Books. 81107. p.

Zinnecker, Jürgen (2006): A fiatalok a társadalmi osztályok terében. Új gondolatok egy régi témához. In: Gábor Kálmán - Jancsák Csaba (szerk.): Ifjúságszociológia. Belvedere, Szeged. 